\section{THE PORTUGUESE IN ARAKAN IN THE SIXTEENTH AND SEVENTEENTH CENTURIES}

\section{Suthachai Yimprasert ${ }^{1}$}

\begin{abstract}
In the kingdom of Arakan, there were thousands of pure and mixed-blood Portuguese staying as freebooters, mercenaries, and merchants. They became mercenaries for the king of Arakan. Some of them rose to obtain important status. The main example was Filipe de Brito who became lord of Syriam from 1602 to 1613. The other one was Sebastião Gonçalves Tibau who became the pirate king of Sandwip from 1609. Although the king of Arakan defeated him in 1617, piracy did not cease until they were suppressed in 1666 because the king of Arakan himself supported the Portuguese pirates and employed them to make trouble for the Moghuls in Bengal.
\end{abstract}

\section{The Kingdom of Arakan}

Arakan was a kingdom on the eastern shore of the Bay of Bengal. ${ }^{2}$ Duarte

1 Ph.D., Assistant Professor, Department of History, Faculty of Arts, Chulalongkorn University, Bangkok, Thailand

${ }^{2}$ Arakan was conquered by Burma in 1782 . Nowadays it is a state in the Union of Myanmar. Its geographical area consists of a long coastal strip, from the Naff estuary in the north to cape Negrais in the south. The coast is studded with islands, of which the most important are Sandoway, Cheduba, Ramree. The area of the province is around 18,540 square miles. The
Barbosa mentions that the kingdom of Arakan had twelve towns. ${ }^{3}$ It was separated from the Irrawadi basin of Burma by the mountain ranges of Arakan Yoma. The Muslims called the Arakanese Magh, but the natives called their land Rakhaingpyi, or the land of the Rakhaing, from which came the name 'Arakan' used by the Europeans. ${ }^{4}$ The Arakanese chronicles themselves go back to 2666 $\mathrm{BC}$., when the first king of Arakan is thought to have emerged. It is accepted that the first kingdom in Arakan dated from the fifth century, when a king of the Chandra Dynasty built Dinnyawadi as his capital, and Arakan became Buddhist. In 1433, the capital was moved to Mrauk-u or Mrohaung. Its proximity to the sea meant the king of Arakan always had ships to trade and had strong naval power.

In 1404, Arakan was invaded by the Burmese army, and King Mengsoamwun went into exile in Bengal, where he stayed for twenty-four years. In 1428, Sultan Nazir Shah of Bengal sent an army to restore him to his seat in Arakan. The attempt was successful and in return Mengsoamwun agreed to be a tributary of

principal rivers are Naaf, Mayu, Lemro, and Koladan.

${ }^{3}$ Duarte Barbosa. 1866. Description of the Coasts of East Africa and Malabar. tr. by Henry E. J. Stanley. London: The Hakluyt Society Publications first serial no. 35, p.182.

4 'Rakhaing' is the same word as the Pali Yakkho or Raksha, which means monster. The term appears to be applied by the Aryan Indians to the people of Dravidian and Mongolian stock, and by the Buddhist Sinhalese to the aborigines in Ceylon. Nevertheless, the Arakanese have not been ashamed to retain the name for themselves as dwellers in Rakhaing-land. See Arthur Phayre. 1883. History of Burma. London: Sesil Gupta., p. 41. 
the sultan of Bengal and added the Muslim name 'Ali Khan' to his title. When he died in 1434, his brother, Mengkari came to the throne and a lso b ore the name A li Khan, but refused to be subordinate to Bengal. At this time, Nicolo di Conti, a merchant of Venice, visited Arakan in 1435 , en route to Ava and Pegu. It is possible that he was the first European who came to this kingdom. But the first Portuguese ship arrived in Arakan during the reign of King Minyaza (r.1501-1523).

King Mengbeng came to the Arakanese throne in 1531. At this time, King Tabinshwehti of Taungoo was building up his power in the Irrawadi Basin. $\mathrm{He}$ conquered Pegu in 1538, and established it as the new capital of the Burmese empire. Thus, Mengbeng had to defend the country from invasion from the east by Tabinshwehti and also raids from the west by the raja of Tippera. In the reign of King Mengphalaung or Sikunder Shah (15711593), the Arakanese recaptured Chittagong from Bengal.

According to the Arakanese chronicle, the first arrival of the Portuguese was in 1532 , when they came 'from the great ocean in big ships'. It was reported that the Portuguese plundered villages near the coast. ${ }^{5}$ However, it is recorded that during the reign of King Minyaza, the Portuguese ships arrived at Arakan. João da Silveira, who was the first Portuguese official to lead a fleet into the Bay of Bengal, made a brief stop over at Akyab in Arakan in 1517, and went further to Chittagong, where his mission failed. He returned to the delta of the river of Arakan and conducted negotiations there. The king of Arakan sent an emissary to Silveira with a friendly

${ }^{5}$ Ibid., pp. 172-173. greeting, a ruby ring, and an invitation to visit the capital. ${ }^{6}$ Though the royal messenger tried to reassure Silveira that he would be received amicably, his experience at Chittagong apparently made him suspicious of treachery. After proceeding upriver a few miles, the Portuguese captain decided to abandon the project, turned his ships around, and set sail for Ceylon.

However, a captain in the fleet, João Fidalgo, rebelled against his commander and returned to Arakan trying to settle an agreement on his own initiative. The king of Arakan ordered an attack on the Portuguese ship. João Fidalgo fought for nearly a day and lost forty men before he was able to escape. He sailed and wandered to many different parts, where some of his men were killed and others were captured without taking any prizes. At last he returned to India when the new governor, Diogo Lopes de Sequeira, pardoned him. ${ }^{7}$

For a long time thereafter, the Portuguese officially expressed a feeling that the Arakanese were false and untrustworthy, and that they should have little to do with them. ${ }^{8}$ However, in 1569 , Cesare Frederici reported that an Arakanese messenger was sent to the Portuguese captain in

${ }^{6}$ Manuel de Faria e Sousa. 1945. Ásia Portuguesa, vol. ii. Porto: Biblioteca História , p. 21.

${ }^{7}$ Fernão Lopes de Castanheda. 1979. História do Descobrimento e Conquista da Índia pelos Portugueses. rev. por M. Lopes de Almeida, Porto: Lello \& Irmão, livro iv, cap'tulo xxxix.

${ }^{8}$ Donald F. Lach. 1965. Asia In The Making of Europe. vol. i The Century of Discovery. Chicago: University of Chicago Press, p. 552. 
Chittagong offering friendship and inviting him to visit the capital of King Minsetya (r.1564-1571). From this period some Portuguese mercenaries began to serve in the Arakanese navy. The combined naval forces of the seagoing Arakanese and the Portuguese increased Arakanese power against both Pegu and Bengal. When in 1575, King Bayinnaung of Pegu determined to subject Arakan to vassalage, he found by no means 'hee is able to doe it: because the King of Pegu hath no power or armie by sea. The king of Arakan was able to equip for war as many as 200 vessels which were clearly enough to defend him against attack by sea. ${ }^{9}$ In the reign of Monyazakayi or Selim Shah of Arakan (r. 1593-1612), although there w as no o fficial c ontact between Arakan and the Estado da India, many Portuguese settled in his kingdom. They became mercenaries who were greatly favoured by the king. A thousand Portuguese served in the army. A regiment of the bodyguards of the royal palace was composed entirely of them. The Portuguese population, including mestiços, numbered about 2,500 in Arakan and Chittagong in $1598 .^{10}$

In 1599, when the Burmese kingdom of King Nandabayin was in ruins, Arakan allied itself with Taungoo to seize Pegu. The Taungoonese were sent to attack Pegu from the north, while the Arakanese fleet came up the river from the south. Pegu had

9 Samuel Purchas (col.). 1905. Hakluytus Posthumus or Purchas his Pilgrimes. vol. $x$. Glasgow: James MacLehose and Sons, p.138.

${ }^{10}$ M. N. Pearson. 1987. The New Cambridge History of India 1.1 The Portuguese in India. Cambridge: Cambridge University Press, p. 84. a very strong artillery unit, but enjoyed no other support, so in March 1600 Nandabayin had to surrender and was taken to Taungoo. ${ }^{11}$ The capital of Pegu was captured, and the spoils were shared between the prince of Taungoo and the king of Arakan. The victor left Pegu deserted for the army of King Naresuan of Siam, who was about to invade Burma. At this point, some Portuguese adventurers came on to the scene. Among them there were two very prominent mercenaries, namely Filipe de Brito e Nicote and Salvador Ribeiro de Sousa.

\section{Filipe de Brito e Nicote}

Salvador Ribeiro de Sousa was a native of Guimarã s, and he came from a highranking noble family for he was mentioned as cavalheiro or knight. ${ }^{12} \mathrm{He}$ came to India and spent seven years under royal service during which time he went to many wars in Malabar, Hormuz, and also joined the army of André Furtado de Mendonça in the war of Jaffnapatnam in 1591. Later, he left the service and became a soldier of fortune in Arakan. He served under the King of Arakan and obtained a captaincy in the native force. As for Filipe de Brito, he was born in Lisbon in the 1550 s, a son of Jules Nicot, probably a brother of Jean Nicot, the French ambassador in Portugal from 1559 to 1561 . Jules Nicot remained in Portugal and became thoroughly naturalised. $\mathrm{He}$ changed his name to Jœlio de Nicote and

\footnotetext{
${ }^{11}$ The story was told by Nicolo Pimenta, Visitor of the Jesuits in India, in Purchas, p. 216.

${ }^{12}$ Manuel de Abreu Mousinho. 1990. Brave Discurso em que se Conta a Conquista do Reino do Pegu na India Oriental. Lisboa: Publicaçóes Europa-América, p.59.
} 
married a Portuguese lady, Marquesa de Brito, a daughter of a Filipe de Brito, who was chamberlain to the Infante Dom Duarte and his sister, D ona M aria, future wife of King Philip II of Spain. ${ }^{13}$

It was noted that Filipe de Brito took his mother's family name because the family was definitely of noble rank and enjoyed such consideration in Portuguese circles. Since the lesser nobility was usually quite poor, the young Filipe de Brito was destined to go to India to carve a name for himself and achieve honour and wealth. Manuel de Abreu Mousinho related that in 1600 , de Brito, "traded in those parts as a merchant for almost twenty years with the protection of the king of Arakan.' 14 Consequently, it is possible that he had arrived in India before 1580. Then, he left the crown service and became a freebooter in Bengal. He practiced several trades including selling charcoal and, later, he a salt merchant and controlled the industry on Sandwip Island with the concession of the king Arakan. This time he entered service as a gunner in the Arakanese armed forces, and be skill and courage, he rose to the rank of commander of a group of Portuguese mercenaties. ${ }^{15}$ He was mentioned in a Jesuit letter as 'a rich and honourable man and the Captain of many Portuguese, whom he

${ }^{13}$ Cayetano J. Socarras. 1966. 'The Portuguese in Lower Burma: Filipe de Brito de Nicote', in LusoBrazilian Review. voliii, no. 2, (December, 1966).

${ }^{14}$ Mousinho, op.cit., p. 60.

${ }^{15}$ Donald F. Lach and Edwin J. Van Kley. 1993. Asia In The Making of Europe vol. iii A Century of Advance. Book iv, Chicago: University of Chicago Press, p. 1124. brought with him to Pegu., ${ }^{, 16}$

In 1599, when the Siamese army was preparing to conquer Pegu, the king of Arakan, allied with the prince of Taungoo, attacked Pegu before the Siamese. The king of Arakan sent his son, Mengkhamong, to command the fleet in the operation. This time, Filipe de Brito, Salvador Ribeiro and the Portuguese mercenaries took an active role. When the prince left Pegu in 1600, he appointed de Brito to lead a corps of Portuguese soldiers, stationed at the chief port of Syriam. Peter Floris, who came to Asia between 1611 and 1615 related that:

The King of Arakan gave the towne or forte of Siriangh, lying uppon the same river of Pegu, in keeping to the Portingalls, especially to Philippe de Britto de Nicote, to whome hee gave the name Xenga, which is honeste; which honour Xenga did afterwards requite very well, taking his sone prisoner some 3 or 4 yeares after, and ransomed him 110,000 tangans and 10 galeas of ryce, so that the sayd Xenga is att this present yett dominering, not caring for any body. ${ }^{17}$

Faria e Sousa described how de Brito persuaded King Selim Shah of Arakan to erect a customs house at Syriam for which

\footnotetext{
${ }^{16}$ Femão Guerreiro. 1930. 'The Mission of Pegu', Jahangir and the Jesuits. tr. by C. H. Payne. London: George Routledge \& son Ltd., p. 194.

${ }^{17}$ W. H. Moreland (tr. and ed). 1934. Peter Floris: His Voyage to East Indies in the Globe, 1611-1615, London: The Hakluyt Society Publications, second serial no. lxxiv, p. 55.
} 
he himself was to be responsible. However, Selim Shah handed control of the fort to an Arakanese noble called Bannadala ${ }^{18}$. Bannadala suspected de Britôs intentions, so he allowed no Portuguese to enter the fort with the exception of Belchior da Luz, a Dominican friar. De Brito appeared to have formed a plan to become master of the town and the port. He therefore decided to use force to expel the Arakanese governor. $\mathrm{He}$, together with three Portuguese $\mathrm{c}$ aptains, Jo ão de Oliva, Paulo do Rego, and Salvador Ribeiro, and fifty Portuguese soldiers, suddenly attacked the fort in 27 February 1602, and drove Bannadala out. Then, de Brito made himself supreme in Syriam but still pretended to depend on Selim Shah. He accused Bannadala of being a sacrilegious robber and offered his own service to build the fort for the Arakanese.

De Brito reconstructed the fort of Syriam with stone walls and a moat around it, and equipped it with guns. António Bocarro related that de Brito wanted 'to establish there a fortress to be turned over to the viceroy of India, from which it would be possible to take over the land of Pegu. ${ }^{, 19}$ At the same time, he began to build a town and encouraged the natives to cultivate the land. Thus, Syriam recovered rapidly, and by 1603 the town had from fourteen to fifteen thousand inhabitants all engaged in cultivating the land. The region soon

\footnotetext{
${ }^{18}$ Manuel de Faria e Sousa. Ásia Portuguesa, vol. v, p. 250.

${ }^{19}$ António Bocarro. 1992. O Livro das Plantas de todas as Fortalezas, Cidades, e Povoações do Estado da India Oriental. 2 vols., rev. por Isabel Cid, Lisboa: Imprensa Nacional - Casa da Moeda, parte i, p. 131.
}

became self-sufficient in rice and the excess was expected to be exported to India. The king of Arakan began to feel alarmed at the independent power of de Brito. The Muslims at the Arakan court and the emissaries of the sultan of Golconda urged him to expel the Portuguese. When de Brito knew, he came to the court and advised the king that the Portuguese were friendly and would help him to fight the Moghuls. At this point, Gaspar da Silva, the ambassador of the viceroy at Goa, arrived with the purpose of making friends. Thus, the king agreed to the Portuguese settlement at Syriam. ${ }^{20}$

As soon as the work at Syriam was sufficiently advanced, de Brito tried to establish himself as an independent prince by sending emissaries to Taungoo, Prome, Chiengmai, Siam and other nearby states to make treaties of friendship. Most returned favourable replies, except for the king of Siam, who was told by Martim de Torres, a Portuguese at Ayuthya, that de Brito had been the slave of Arakan and was never recognised by Goa. ${ }^{21}$

In 1603, after de Brito fortified Syriam for a year, it seems that he had a huge scheme to establish Portuguese mastery over all Bengal, Burma, and Siam. To achieve this scheme, he needed not only recognition, but also strong support from the king of Spain and Portugal. For this reason, he sailed to Goa to meet Aires de Saldanha, the Portuguese viceroy, to propose his plan. At the same time, he dispatched a report to Lisbon along with a petition asking for

\footnotetext{
${ }^{20}$ Fernão Guerreiro, op,cit. p. 196.

${ }^{21}$ Donald F. Lach and Edwin J. Van Kley, op.cit., p. 1125.
} 
official appointment as commander of Syriam for life, for a portion of the port revenues, and for the right of succession for his son. ${ }^{22}$

His report included ten good reasons for taking over the states around the Bay of Bengal. First, the crown would be able to reclaim for its service the twenty-five hundred Portuguese and mestiços who, as outlaws or refugees, worked for the 'gentile' or 'Moorish' kings of the region; second, the collection of customs would provide additional revenues for the Estado da India; third, the ships for armadas of India could be built very cheaply in Pegu and elsewhere, because all the timber required for ship-building grew abundantly; fourth, from these ports supplies and munitions could be sent to Melaka and other places in the South in all seasons and more easily than from Goa from where they could only be sent once a year on account of the monsoons; fifth, from Pegu it would be simple for the Portuguese fleets to subdue Martaban, Tavoy, Tenasserim, Lancalam, and Kedah, all of which were in the hands of the king of Siam; sixth, the occupation and development of Pegu as a Portuguese base would put an end to Siamese ambitions and pretensions in this area; seventh, from Pegu the Portuguese could command the nearby seas just as they commanded the coast of Malabar; eighth, from Syriam the Portuguese could subdue Taungoo in two years, confiscate the vast treasure kept there and extend their authority along the whole coast of Martaban; ninth, by means of this conquest, the Portuguese would check the spread of the Dutch and prevent them setting foot in Pegu and many other

\footnotetext{
${ }^{22}$ Fernão Guerreiro, op.cit., . p. 262.
}

kingdoms; and tenth, of far more value than the temporal gains or wealth, were the countless souls that could be won among these people who 'are by nature docile and easy to convert'. ${ }^{23}$

De Brito l eft Salvador Ribeiro in charge of Syriam. Not long after de Brito departed, Selim Shah decided to expel the Portuguese by sending an army of 6,000 led by Bannadala to attack the town, but the Arakanese army was defeated. After that Selim Shah tried a second and third time to put down the mercenaries who rebelled against him by sending more troops, with the help of the Burmese prince of Prome, but Salvador Ribeiro defended the fort vigorously. The Arakanese army continued the siege of Syriam for eight months yet could not subdue it before reinforcements arrived from Goa. Again Ribeiro was victorious. ${ }^{24}$

On the way to Goa, de Brito stopped at Cochin to request the provincial of the Jesuits to dispatch priests to Syriam. Once he reached Goa, his mission was successful, because the viceroy not only complied with every demand de Brito made of men and munitions, but also married him to Luísa de Saldanha, a niece of his who had been born in Goa of a Javanese woman. The viceroy gave him the titles of 'Commander of Syriam' and 'General of the Conquest of Pegu', and if he had a legitimate son, the title would be inherited by him. Later, in the letter of Dom Filipe II to Martim Afonso de Castro the viceroy on 2 March 1605 , it was confirmed that the king knew and recognised the status of Filipe de Brito, and even a warded $h$ im the knighthood of

${ }^{23}$ Ibid., pp. 201-206.

${ }^{24}$ Mousinho, op.cit., pp. 79-114. 
the Order of Christ. ${ }^{25}$ In an other letter in 1607, Dom Filipe II recommended de Brito to make forecasts about the conquest of Pegu and Sandwip. ${ }^{26}$

When de Brito returned to Syriam, Goa reinforced his power with six warships and 3,000 soldiers. Ribeiro handed over the government of Syriam to de Brito and retired to Portugal where he died a poor man. ${ }^{27}$ At this point, de Brito was able to maintain Portuguese power in Lower Burma. He repaired the fort, built a church, and sent rich presents to the king of Arakan who had sent an envoy to compliment him upon his arrival. He then issued orders with regard to the customs house there, in accordance with the instruction of the viceroy, obliging all vessels that traded on the coast of Pegu to make their entry there.

Then, in 1604, the king of Arakan sought again to recapture Syriam. He tried to persuade the king of Taungoo to join him, by sending an ambassador with twenty boats to Taungoo, but de Brito sent Bartolomeu Ferreira to capture them. Selim Shah now gathered 700 small vessels with 4,000 men to attack Syriam, under the command of his son

${ }^{25}$ ANTT. Livro das Monções, livro 1, fol. 31, Carta régia ao vise-rey pede-lhe informação dos serviço de Filipe de Brito, 2 de Março de 1605.

${ }^{26}$ ANTT. Livro das Monções, livro 1, fol.145, Carta régia ao vise-rey fez mercê a filipe de Brito recommenda que se preveja sobre a conquista de Pegu ilha da Sandiva, 23 de Janeiro de 1607.

27 J. J. A. Campos. 1919. History of the Portuguese in Bengal. Calcutta: Butterworth \& Co., p. 80.
Mengkhamaung. At first, the Arakanese were at an advantage. Paulo do Rego, the Portuguese commander blew up his ship and himself, for he did not want to fall into the hands of the enemy. But later, the Arakanese operation was, again, a disastrous failure. The prince was taken prisoner by the Portuguese in January 1605. The king of Prome sent the army to rescue the Arakanese prince but lost to de Brito as well. De Brito was inclined to treat the prince of Arakan with great respect. Nevertheless, he demanded a ransom of 50,000 ducados for his release. Selim Shah, sooner than submit to these terms, determined to make another attempt to take the port. He joined forces with the king of Taungoo, and brought a more formidable army to the attack by land and sea. The allied force besieged the city for several months. Owing to some suspicion, the king of Taungoo suddenly quit the field one night. The Arakanese army was not able to defeat Syriam alone. The king of Arakan had to pay the ransom to have the prince released. ${ }^{28}$

However, the dispute still went on. In 1607, when de Brito sent an envoy to Mrauk-u to beg for the port of Dianga, Selim Shah killed the envoy and sent troops to destroy the Portuguese community at this port. ${ }^{29}$ Moreover, he tried to make an alliance with other Europeans against de Brito in 1608, when he offered to let the Dutch trade and build fortifications in Arakan in return for help in driving the Portuguese out of Syriam. The Dutch declined the offer because the

\footnotetext{
${ }^{28}$ Arthur Phayre, op.cit., p. 126.

${ }^{29}$ Manuel de Faria e Sousa. Ásia Portuguesa, vol. v, p. 285.
} 
commitments the king required were too great. $^{30}$

After defeating the Arakanese in 1605, the Portuguese at Syriam became an independent state in lower Burma. Binyatala, the Mon lord of Martaban who was a tributary of Siam, sought de Britôs friendship, and even the king of Taungoo entered into an alliance with him to fight with the king of Ava. De Brito married his son, Simão, to a daughter of Binyatala. Now that his position was more secure, he started to make money as quickly as possible and tried to force all the inhabitants of his small kingdom to be Christians. He built a monastery called São Tomé, in which friar António de Olivais, a Dominican, became the first preacher to work. On the grounds that all idolatry must be suppressed, and with the full approval of the friars representing the archbishop of Goa, he looted all the Buddhist temples of their ornaments and treasures, melted down all the golden images, and cast the bronze from the bells into cannons. ${ }^{31}$

Nevertheless, his adventures continued, because there was a contest for supremacy in Burma between the kings of Taungoo, Prome and Ava. Yet King Anaukpetlun (r. 1605-1628) of Ava became so strong that, in 1608, he defeated Prome. Then in 1610 , he led an army to subdue Taungoo, but, in fact, the king of Taungoo surrendered and he himself escaped to Syriam. Two-thirds of the population in Taungoo was, thereafter, taken to A va in

${ }^{30}$ G. E. Harvey. 1925 A History of Burma. London: Frank Cass \& Co. Ltd., p. 141.

${ }^{31}$ Maung Htin Aung. 1967. A History of Burma. New York: Columbia University Press, p. 137.
Upper Burma. De Brito took the opportunity to join with Martaban and plundered Taungoo in 1612. At this point, King Anaukpetlun decided to subdue de Brito once and for all. ${ }^{32}$

In 1613, the great Burmese army from Ava marched to attack Syriam. Faria e Sousa recounted that the massive army consisted of 120,000 men and forty ship. ${ }^{33}$ The war started on 19 February, when the fortress was in a weak state. De Brito had with him only 100 Portuguese and 3,000 native soldiers and very little gunpowder. $\mathrm{He}$ sent his soldiers to buy gunpowder at Bengal and asked for a supply from São Tomé de Meliapor. He was waiting for ships from Goa to support him, but the ships did not come in time when the Burmese army attacked. He tried to beg for mercy, sending Sebastião Rodrigues as an envoy with the proposal to surrender if the king of Ava would grant them their lives and allow them to depart in a ship, but the king refused to receive the envoy. The king of Arakan, his enemy who nevertheless was afraid of the invasion of the king of A va, s ent fifty s hips to a ssist him, all of which were seized by the Ava army. After a siege of thirty-seven days, the Burmese army dug a tunnel under the town walls and rushed into the city. De Brito was captured, impaled on a tall stake for three days and then executed. His wife and other members of his household were transported as slaves to Ava. The former king of Taungoo and friar Manuel Ferreira who came from Bengal and stayed at

32 Victor B. Lieberman. 1984. Burmese Administrative Cycles: Anarchy and Conquest, $c$ 1580-1760 Princeton, New Jersey: Princeton University Press, p. 54.

${ }^{33}$ Bocarro, parte i, p. 117. 
Syriam from 1607, were executed as well. ${ }^{34}$ However, the Burmese king chose to spare the followers of de Brito, because he needed their skills in the use of guns and cannons. Thus, all of them were brought to settle at Ava. Peter Floris, who was at Masulipatnam on the Coromandel, wrote that the 'King of Ava take the fort of Siriang and slaye all the Portingalls and that Xenga or Philip was either spitted or soulathd. This was done in Marche laste. ${ }^{35}$

As soon as the viceroy of Goa heard of the siege of Syriam, he dispatched Diogo de Mendonça Furtado with five ships to relieve it, but it was too late. When the fleet arrived at Martaban, they heard of the fall of Syriam, so there was no point in going further. As for the lord of Martaban, he had to surrender to Ava. King Anaukpetlun ordered him to kill Sim<o de Brito, the son of Filipe de Brito, who had married a princess of Martaban.

\section{Portuguese Piracy}

At the beginning of the seventeenth century while the Moghuls held power over Bengal, the port city of Chittagong was in the hands of the king of Arakan. There were a number of Portuguese, not subject to control from Goa settled in this city, who made the city remain a thriving place, so the king of Arakan was pleased to have the Portuguese staying in his kingdom. Pyrard de Laval, who came to Chittagong in 1607 , mentioned that:

${ }^{34}$ Arthur Phayre, op.cit., p. 129.

${ }^{35}$ W. H. Moreland (tr. and ed), op.cit., pp. 128-129.
A large number of Portuguese dwell in freedom in the ports on this coast of Bengal; they are also very free in their lives, being like exiles. They do only traffic, without any fort, order, or police, and live like natives of the country; they durst not return to India, for certain misdeeds they have committed, and they have no clergy among them. ${ }^{36}$

In 1590, António de Sousa Godinho was the Portuguese official sent from Goa to Arakan for friendship. In a little document about this man, Couto mentions that he was an official who was sent to Pegu with three ships.$^{37} \mathrm{He}$ obtained royal permission from the king of Arakan, to establish a fort at Dianga, a port opposite Chittagong, and António de Sousa Godinho established his own power on the island of Sandwip in the mouth of the Magna River. ${ }^{38}$ This island was a trade centre, which commanded the mouth of the Ganges-Brahmaputra, and its neighbourhood provided timber in abundance for shipbuilding. The island itself was very important because it was a place producing salt to supply the whole of

${ }^{36}$ Pyrard de Laval. 1887. The Voyage of François Pyrard of Laval to the East Indies, the Maldives, the Moluccas and Brazil. vol. i, London: The Hakluyt Society Publications, first serial no. lxxvi, lxxvii, lxxx, p. 334.

37 Maria Ana Marques Guedes. 1991. Interferência e Integração dos Portugueses na Birmânia ca 1580-1630, Lisboa: Fundação Oriente, p. 107.

${ }^{38}$ J.H. da Cunha Rivara (ed.). 1992. Archivo Portuguez-Oriental. fasciculo iii, New Delhi: Asian Educational Service, 1877 reprinted 1992. p. 257. 
Bengal. ${ }^{39}$ Thus, a number of Portuguese went there and settled down as merchants. Some of them from this island entered the service of the king of Arakan. Despite its importance, António de Sousa Godinho left the island because he thought that it was not necessary for the Estado da India to have a fort there. It was not on the sea route and it would be inconvenient for the Estado da India to send soldiers for fortification. Then, in a letter of 1591, Dom Filipe I stressed that there was little sense for the Portuguese state to expand in that direction.

The island of Sandwip came under the possession of Portuguese privateers in 1602, when Domingos Carvalho and Manuel Mattos led a Portuguese band to capture it and deprived Cedarei, the raja of Siripur, of power over it. Domingos Carvalho was born in Montagil and, probably, came from a lower noble family. He came to India as a soldier of the Estado da India before becoming a privateer in Bengal. He appeared as a captain of the Portuguese mercenary force under the service of the raja of Siripur who had control over the island of Sandwip. In 1602 , while Siripur was at war with the Moghuls, Carvalho took the opportunity to seize the island for himself. He asked for assistance from Manuel de Mattos who, at that time, was the Portuguese captain of Dianga. Trindade described Manuel de Mattos as a man of noble origin who 'was a good and devoted Christian and did good service for his majesty'. He was the captain of all the Portuguese in the region and was accepted by the king of Arakan as

${ }^{39}$ Bocarro, parte ii, pp. 432-433. being the governor of Bengal. ${ }^{40} \mathrm{He}$ came with 400 men and helped Carvalho to beat Cedareis army. In 1603, Selim Shah, the king of A rakan, s ent a fleet to a ttack the Portuguese at Dianga and Cedarei also sent troops to join him. However, the Portuguese defeated the Arakanese. At last, the king of Arakan concluded a peace treaty with the Portuguese and allowed them to dominate Dianga and Sandwip.

Hence, Manuel de Mattos, and Domingos Carvalho divided the island of Sandwip between them. In 1604, Domingos Carvalho wrote a letter to the king of Portugal, asking Lisbon for assistance in the form of ships and artillery, telling the king that he had conquered the island in the name of the Portuguese king. In recognition of their brilliant services, Dom Filipe II made Manuel de Mattos and Domingos Carvalho Fidalgos da Casa Real and bestowed on them the Merit Order of Christ (Habito Mercê de Christo).${ }^{41}$ However, before receiving the award, Domingos Carvalho was invited to the court of the raja of Chandikan, and was poisoned by the raja in 1605 , leaving Manuel de Mattos in sole possession of the island. ${ }^{42}$ Manuel de Mattos c ontrolled the trade from Dianga and Sandwip with the help of a resolute Afghan Muslim named Futteh Khan, who was in Portuguese

${ }^{40}$ Frei Paulo da Trindade. 1912. Conquista Espiritual do Oriente. parte 3, Lisboa: Centro de Estudos Históricos Ultramarinos, pp. 332-334.

${ }^{41}$ ANTT. Livro das Monções, livro 1, fol. 31, Carta régia ao vise-rey pede-lhe informação dos serviços de Filipe de Brito, 2 de Março de 1605.

${ }^{42}$ ANTT. Livro das Monções, livro 2, fol. 41, Carta régia ao vise-rey refere as informação mandadas por Filipe de Brito sobre a paz que faz com o rei de Arrão, 4 de Janero de 1608. 
employment.

The situation was fine as far as the Portuguese were concerned until 1607, when the Arakanese army invaded the islands and massacred around 600 Portuguese r esiding there. The reason for this event related more to the deeds of Filipe de Brito at Syriam than to the fault of the Portuguese at Dianga and Sandwip. Manuel de Mattos was killed in this Arakanese invasion. Yet a few Portuguese escaped into the jungle or by sea, including one, Sebasti<o Gonl alves Tibau. ${ }^{43}$ Later on, he established himself on the delta island of Sandwip, declared himself ${ }^{\circ}$ lord and maintained power there from 1609 to 1617 .

Tibau was a native of the village of Santo António do Tojal near Lisbon. ${ }^{44}$ Since he derived from humble origin, there is no record of the year of his birth and even of his life before he came to India in 1605 . Then, when he came to notice for the first time, the Portuguese official even mistook his name as 'André Gonçalves Traçado. ${ }^{.45}$ $\mathrm{He}$ came to India with a number of his relatives, and was accompanied by at least one cousin, António Carvalho Tibau. After arriving in Goa, Sebastião Gonçalves Tibau served as a soldier for a short time. Subsequently, he went out of royal service,

${ }^{43}$ Bocarro, parte ii, p. 432

${ }^{44}$ Sebastian Manrique. 1926. The Travels of Sebastian Manrique 1629-1643. vol. i Arakan tr. by Lt. Col. C. Eckford Laurd, London: The Hakluyt Society Publications, second serial no. lix, p. 303

${ }^{45}$ ANTT. Livro das Monções, livro 3, fol. 99, Carta régia ao vise-rey sobre a conservação da fortaleza de Sirião e tomada da ilha de Sandiva, 20 de Fevereiro de 1610. moved over to Bengal and engaged in the salt trade that was flourishing at that time. $\mathrm{He}$ soon earned enough from this trade to purchase a small vessel which he employed to trade along the coast of the Bay of Bengal. In 1607, he carried a cargo of salt to Dianga. When the king of Arakan began his attack, Tibau and nine or ten other Portuguese were able to escape to their ships. Afterwards, they, together with others who had escaped at Dianga, sought a way of 1 ife in piracy. They had between them nine or ten vessels, and used these to plunder the Arakanese coast for some time. They found refuge when necessary in the mouth of the Megna. There lay the small territory of the raja of Bakla, with whom these Portuguese pirates were on friendly terms.

After the death of Manuel de Mattos, Futteh Khan made himself the lord of Sandwip with the assistance of the Muslim community there. In 1608 , he wanted to get rid of the Portuguese pirates, but was killed in a naval battle with them. At this moment, other Portuguese from Bengal and neighbouring ports came to join the pirate band, and they agreed to elect Sebastião Gonçalves Tỉbau as their leader. In March 1609, Tibau, with the helping hand of the raja of Bakla, led the Portuguese in an attack on the island of Sandwip. They were opposed by the Muslims led by a brother of Futteh Khan. When the Portuguese besieged the fort of Sandwip for two months, they were running short of both provisions and ammunition. A Spanish vessẹl, led by Gaspar de Pina, a rrived a t D ianga just in time and rendered assistance. ${ }^{46}$ As a result, the Portuguese were able to take the island,

${ }^{46}$ Bocarro, parte ii, p. 437. 
and Tibau became the new master. $\mathrm{He}$ ordered all the Muslims on the island killed. ${ }^{47}$

Tibau governed Sandwip as an independent principality. $\mathrm{He}$ commanded around 1,000 Portuguese, 2,000 native soldiers, 200 horses, and eighty vessels. $\mathrm{He}$ erected a customs house and controlled trade. Being strong enough, he refused to acknowledge the power of the raja of Bakla, and also took possession of adjacent islands. At this time, Filipe de Brito proposed to him that they join forces and include the other Portuguese outlaws of Bengal, but Tibau and the Portuguese community at Chittagong refused to recognise Filipe de Brito as master, and so his attempts were fruitless. Even Dom Filipe II realised that Tibau and de Brito had 'many difference and little ground for agreement'. 48

Later on, Tibau waged war upon the king of Arakan with such success that Selim Shah moved to conclude a peace deal with him. At this time, the Moghul governor of Bengal, undertook to conquer Siripur and Bhulua which lay next to Sandwip. ${ }^{49}$ Realising this danger, Tibau entered into an a greement with the king of A rakan to oppose the Moghuls. The arrangement was that if there was an attack from the Moghuls, Tibau should prevent it

${ }^{47}$ Ásia Portuguesa, vol. v, pp.287-289

${ }^{48}$ ANTT. Livro das Monções, livro 6, fol. 147, Carta regia ao vise-rey sobre se Mandar uma armada ao Pegu para conservasão fortaleza de Sirião e a ilha de Sandiva, 15 de Março de 1613.

${ }^{49}$ ANTT. Livro das Monções, livro 5, fol. 89, Carta regia ao vise-rey sobre o Mogor que enviou um exercito a Bengala, 17 de Março de 1612. advancing further from Bhulua until the king of Arakan arrived to repel them. In support of his promise Tibau sent a nephew of his with some other Portuguese to Mrauk-u as hostages.

However, in 1611, when the king of Arakan waged war with the Moghul viceroy of Bengal, Tibau did not keep the promise. He left the Arakanese army to fight alone with the Moghuls. It was thought either that he had accepted a bribe not to interfere or that he had acted to avenge the death of the Portuguese at Dianga. As a result, Selim Shah lost the war and had to flee from Bhulua to Chittagong. Tibau gathered his fleet at the island of Deserta, and invited the commanders of the A rakan fleet to c ome aboard his ship, murdered them, then seized their ships and either made the crew slaves or killed them. After that, Tibau sent several ships to plunder many villages along the Arakanese coast. In revenge, the king of Arakan killed Tibau's nephew who was kept as a hostage. However, Tibau, to whom treachery and insolence were ordinary affairs, had no feeling for a nephew. ${ }^{50}$

In 1612, King Selim Shah of Arakan died. His son, Mengkhamaung, was crowned as Husain Shah. Prince Anaporum, the governor of Chittagong and a younger b rother of the king had a disagreement with the succession. They fought each other in a battle, in which Anaporum was defeated. Thus, he fled to Sandwip for assistance. Tibau welcomed the prince and married his daughter. Shortly after, Anaporum died and then Tibau seized all his treasure. It was suspected that he had caused the prince's death. ${ }^{51}$

\footnotetext{
${ }^{50}$ Ásia Portuguesa, vol. v, p.192
} 
Husain Shah prepared to get further revenge on Tibau by attacking Sandwip again, but he came face to face with the army of the raja of Tippera and had to suspend the project. This time, Tibau sent messengers to ask for the support of Jerónimo de Azevedo, the viceroy of Goa, arguing that all he had done was to avenge the murder of the Portuguese at Dianga and offering to pay a yearly tribute to the crown of Spain and Portugal. $\mathrm{He}$ suggested that Arakan should be attacked, because the conquest would be easy and great b ooty w ould be found. The viceroy approved of the plan and the king of Portugal decided to award Tibau a Merit Order of Christ for the service of Sandwip. ${ }^{52}$ Thus, in September 1615, the viceroy sent a fleet commanded by Francisco de Meneses Roxo to Arakan with the plan that Tibau would come to join the operation. The Portuguese attacked Mrauk-u on 3 October 1615, but the king of Arakan, with the help of the Dutch, was able to drive out the Portuguese. Francisco de Meneses Roxo was slain in the battle, and Luís de Azevedo took command. They retreated to Sandwip and Luís de Azevedo decided to return to Goa, although Tibau repeated requests not to do so. Many of Tibau's men took this opportunity to abandon Sandwip and returned to Goa with Luís de Azevedo. ${ }^{53}$

\footnotetext{
${ }^{51}$ Bocorro, parte ii, p. 439.

${ }^{52}$ ANTT. Livro das Monções, livro 8 fol. 189, Carta regia ao vise-rey trata da pretenso de Sebastião Gonçalves Tibau de se lhe confirmar a posse da ilha de Sandiva, 21 de Fevereiro de 1615.

${ }^{53}$ Bocorro, parte ii, p. 456.
}

Then, in 1616, the Arakanese fleet with the help of the Dutch counter-attacked Sandwip. This time the king of Arakan won. He destroyed Portuguese power on the island. Tibau escaped to Bengal and stayed there for the rest of $h$ is 1 ife. ${ }^{54}$ The viceroy, Conde de Redondo, claimed that, 'he was not subjected to the order of His Majesty and the Viceroy, he made his own profit, and possessed Sandwip as his own kingdom' ${ }^{55}$ However, the king of Portugal insisted on honouring Tibau and asked the viceroy about him. It was too late because Tibau had died a year earlier at Hughli. ${ }^{56}$

However, Portuguese activities still carried on in the Bay of Bengal. This was because the king of Arakan had not intended to destroy or drive them all away, he only wanted to control and enlist them in his service. As For the rest of the Portuguese community at Sandwip after 1617, they were all moved to Dianga with their mestiços. The community had as its leaders friar André Pereira, a Jesuit, and Gaspar Pacheco de Mesquita, a noble. ${ }^{57}$ The king of Arakan wanted to employ them as a force to guard his northwest

\footnotetext{
${ }^{54}$ Maria Ana Marques Guedes. Interferência e Integração dos Portugueses na Birmânia ca 1580-1630, pp. 168-169.
}

${ }^{55}$ ANTT. Livro das Monções, livro 10, fol. 470, Resposta do Vice-Rei à Carta Régia, 3 de Fevereiro de 1618.

${ }^{56}$ ANTT. Livro das Monções, livro 11, fol. 171, Carta Régia para o vise-rey orderna que se lance o habito de cristo a Sebastião Gonçalves Tibau, 16 de Fevereiro de 1618

${ }^{57}$ ANTT. Livro das Monções, livro 11, fol. 172, resposta a carta régia, 18 de Fevereiro de 1619. 
frontier and contain any advance by the Moghuls, because he realised that these Portuguese could be formidable fighting men and their seamanship was very good. Moreover, their knowledge of firearms and cannons was superior to that of the forces of the Moghuls. Hence, he supported and encouraged them to raid westward into Bengal.

Now the Portuguese adventurers here became pirates and joined hands with the native Arakanese to attack the GangesBrahmaputra delta. The pirates operated from Chittagong and Dianga in the kingdom of Arakan. The spoils were shared half and half between the pirates and the Arakanese court. The slaves could be sold in Arakan for the Arakanese to use in agriculture; otherwise, the Portuguese merchants could sell them in any other ports of Coromandel. ${ }^{58}$ Even the Dutch, who came to Arakan in 1608 and later always s ent their v essels from $B$ atavia to Chittagong to buy rice, irregularly bought the Bengali slaves. ${ }^{59}$ The piracy was so terrifying that the Moghul governor at Dacca stretched iron chains across the river to defend the city. Shiab-uddin Talish, a Moghul historian, related that:

The Arakan pirates, both Maghs and feringi, used constantly to come by the water-route and plunder Bengal. They carried off such Hindus and Moslems as they could seize, pierced the palms of their hands, passed thin

58 Jadunath N. Sarkar 1907. 'The Feringi Pirates of Chatgaon, 1665 A.D.' in Journal of Asiatic Society of Bengal, vol. iii n० 6 (June, 1907), pp. 422-423.

${ }^{59}$ D. G. E. Hall. A History of South-East Asia, pp. 357-362. slips of cane through the holes and shut them huddled together under the decks of their ships. Every morning they flung down some uncooked rice, as we do for fowl...Many high born persons...many...pure women, were compelled to undergo the disgrace of slavery or concubine...Not a house eventually was left in habitude on either side of the rivers lying on their track from Chittagong to Dacca. The district of Bakla, which formerly a bounded in houses and cultivated fields and yielded a large revenue as duty on betel-nuts, was swept so clean with their broom of plunder and abduction that none was left to tenant any house or kindle a light in that region. ${ }^{60}$

In 1628, Friar Sebastião Manrique arrived at Bengal, where he witnessed the activity of the pirates. When he went to the island of Saugar, which lay opposite Hijili at the mouth of the Hughli River, he was told that the island had formerly been flourishing. Since it was always looted by the pirates who kidnapped its inhabitants and sold them as slaves, the people had fled, and left the place in ruins. In 1629 the friar himself went to Dianga and stayed there. There were around 750 Portuguese, of pure or half blood, resident in this city and the neighbouring villages. These people were organised into companies under their captains, to whom the king of Arakan had granted estates and given revenue. The friar said that when he lived

${ }^{60}$ Quoted in G. E. Harvey, op.cit., pp. 143-144. 
in Arakan, the pirates usually raided Bengal three or four times a year and he perceived that the piracy went on by the informal approval of the Estado da India as he related, 'this raiding was pronounced by the Provincial Council at Goa to be just, since the Mogors were not only invaders and tyrannical usurpers but also enemies of Christianity. ${ }^{61}$

There was a Portuguese community not only at Chittagong and Dianga, but also at Mrauk-u. Manrique reported that the community was outside the wall at a village on the bank of the river. This place was called Daingri-pet on the western side of the city. When Wouter Schouten, a Dutch merchant, came to Arakan in 1660 , he told of a large number of foreigners staying in Mrauk-u for trade and employment, especially the Portuguese who lived in a village three miles from the capital. They w ere e mployed by the king as soldiers and sailors. Some were married to Portuguese women and others to Arakanese who had converted to Catholicism. Then, the Portuguese helped the Arakanese in building the fort at Mrauk-u with stone as well. ${ }^{2}$

The Moghul governor of Bengal was determined to annihilate the pirates at Chittagong. D uring the period from 1656 to 1664 , the campaign was planned twice, but not executed for various reasons. Matters changed in 1664 , when sixty or seventy pirate vessels were reported to have captured as many as 160 boats of the imperial flotilla. L ater the same year, the pirates w ere reported to have $\mathrm{c}$ aptured in

\footnotetext{
${ }^{61}$ Manrique, vol. i Arakan, p. 286.

${ }^{62}$ Maurice Collis. The Land of The Great Image, p. 144.
}

one raid between 2,700 to 2,800 Bengalis from Bhushna to be sold as slaves. This time the Bengali authorities of Governor Shayista Khan were ordered to reorganise their flotilla and execute the campaign. In March 1664, Shayista Khan commanded the ship-builders in Bengal to build as many ships and boats as possible, and also requested the Dutch and the English to join forces with him against the Arakanese. The Director of the Dutch East India Company, who was eager to remove Portuguese power, dispatched two war ships from Batavia to join the Moghuls. ${ }^{63}$

When the preparations were ready in 1665 , Shayista Khan unleashed a massive force to attack Chittagong and the other islands and waged war with both the Portuguese pirates and the Arakanese. This time the Moghuls won, and the Portuguese pirates were wiped out from their stronghold around the mouth of the Megna river and Sandwip. King Sandathuthamma of Arakan (r. 1652-1684) suffered a severe defeat. The Moghul army captured 1,026 cannons and 135 ships, and killed a lot of Arakanese soldiers. Thousands of others were taken prisoner and sold as slaves. After defeating the Arakanese, Shayista Khan annexed the Chittagong district to the empire of Aurangzib and renamed the city Islamabad. ${ }^{64}$

It should be noted that even at this time the Moghuls did not act against all the Portuguese. In fact when Shayista Khan was bent upon the conquest of Chittagong, he sent his man to the Portuguese settlers

\footnotetext{
${ }^{63}$ Anjali Chatterjee. Bengal in the Reign of Aurangzib 1658-1707, p.25.

${ }^{64}$ Chatterjee, Ibid., pp. 26-27.
} 
trading in salt in Loricul near Dacca asking their countrymen in Chittagong to abandon the king of Arakan and enter the Moghul service. ${ }^{65}$ However, the Portuguese there could not change the mind of the Portuguese at Chittagong.

\section{References}

Abreu Mousinho, Manuel de. 1990. Brave Discurso em que se Conta a Conquista do Reino do Pegu na India Oriental. Lisboa: Publicaçóes Europa-América.

ANTT. Livro das Monções, livro 1, fol. 31, Carta régia ao vise-rey pede-lhe informação d os serviço de F ilipe de Brito, 2 de Março de 1605.

ANTT. Livro das Monções, livro 1, fol.145, Carta régia ao vise-rey fez mercê a filipe de Brito recommenda que se preveja sobre a conquista de Pegu ilha da Sandiva, 23 de Janeiro de 1607.

ANTT. Livro das Monções, livro 2, fol. 41, Carta régia ao vise-rey refere as informação mandadas por Filipe de Brito sobre a paz que faz com o rei de Arrão, 4 de Janero de 1608.

ANTT. Livro das Monções, livro 3, fol. 99, Carta régia ao vise-rey sobre a conservação da fortaleza de Sirião e tomada da ilha de Sandiva, 20 de Fevereiro de 1610.

ANTT. Livro das Monções, livro 5, fol. 89, Carta regia ao vise-rey sobre o Mogor que enviou um exercito a Bengala, 17 de Março de 1612.

ANTT. Livro das Monções, livro 6, fol. 147, Carta regia ao vise-rey sobre se Mandar uma armada ao Pegu para conservasão fortaleza de Sirião e a

65 J. J. A. Campos, op.cit., p. 89. ilha de Sandiva, 15 de Março de 1613.

ANTT. Livro das Monções, livro 8 fol. 189 , Carta regia ao vise-rey trata da pretenso de Sebastião Gonçalves Tibau de se lhe confirmar a posse da ilha de Sandiva, 21 de Fevereiro de 1615.

ANTT. Livro d as Monções, 1 ivro 10, fol. 470, Resposta do Vice-Rei à Carta Régia, 3 de Fevereiro de 1618.

ANTT. Livro d as Monções, livro 11, fol. 171, Carta Régia para o vise-rey orderna que se lance o habito de cristo a Sebastião Gonçalves Tibau, 16 de Fevereiro de 161.

ANTT. Livro d as Monções, livro 11, fol. 172 , resposta a carta régia, 18 de Fevereiro de 1619.

Barbosa, Duarte. 1 866. Description of the Coasts of East Africa and Malabar (tr.) by Henry E. J. Stanley. London: The Hakluyt Society Publications first serial no. 35 .

Bocarro, António. 1992. O Livro das Plantas de todas as Fortalezas, Cidades, e Povoações do Estado da India Oriental. 2 vols., rev. por Isabel Cid, Lisboa: Imprensa Nacional - Casa da Moeda, parte $\mathrm{i}$.

Campos, J. J. A.. 1919. History of the Portuguese in Bengal. Calcutta : Butterworth \& Co.

Chatterjee, Anjali. Bengal in the Reign of Aurangzib 1658-1707.

Collis, Maurice. The Land of The Great Image.

Cunha Rivara, J.H. da (ed.). 1992. Archivo Portuguez-Oriental. fasciculo iii, New Delhi: Asian Educational Service, 1877 reprinted 1992.

Faria e Sousa, Manuel de. 1945. Ásia Portuguesa, vol. ii. Porto: Biblioteca Historia. 
Faria e Sousa, Manuel de. Ásia Portuguesa, vol. v.

Laval, Pyrard de. 1887. The Voyage of François Pyrard of Laval to the East Indies, the Maldives, the Moluccas and Brazil. vol. i, London: The Hakluyt Society Publications, first serial no. lxxvi, lxxvii, lxxx.

Guedes, Maria Ana Marques. 1991. Interferência e Integração dos Portugueses na Birmânia ca 1580 1630, Lisboa: Fundação Oriente.

Guerreiro, Femão. 1930. 'The Mission of Pegu', Jahangir and the Jesuits. (tr.) by C. $\mathrm{H}$. Payne. London: George Routledge \& son Ltd..

Harvey, G. E. 1925 A History of Burma. London: Frank Cass \& Co. Ltd..

Lach, Donald F. 1965. Asia In The Making of Europe. vol. i The Century of Discovery. Chicago: University of Chicago Press.

Lach, Donald F. 1993. Asia In The Making of Europe vol. iii A Century of Advance. Book iv, Chicago: University of Chicago Press.

Lieberman, Victor B. 1984. Burmese Administrative Cycles: Anarchy and Conquest, c 1580-1760 Princeton, New Jersey: Princeton University Press.

Lopes de Castanheda, Fernão. 1979. História do Descobrimento e Conquista da Índia pelos Portugueses. rev. por M. Lopes de Almeida, Porto: Lello \& Irmão, livro iv, cap'tulo xxxix.

Maung Htin Aung. 1967. A History of Burma. New York: Columbia University Press.

Manrique, Sebastian. 1926. The Travels of Sebastian Manrique 1629-1643. vol. i Arakan (tr.) by Lt. Col. C. Eckford Laurd, London: The Hakluyt Society Publications, second serial no. lix.
Moreland, W. H. (tr. and ed). 1934. Peter Floris: His Voyage to East Indies in the Globe, 1611-1615, London: The Hakluyt Society Publications, second serial no. lxxiv.

Pearson, M. N. 1987. The New Cambridge History of India 1.1 The Portuguese in India. Cambridge: Cambridge University Press.

Phayre, Arthur. 1883. History of Burma. London: Sesil Gupta.

Purchas, Samuel (col.). 1905. Hakluytus Posthumus or Purchas his Pilgrimes. vol. $x$. Glasgow: James MacLehose and Sons.

Sarkar, Jadunath N. 1907. 'The Feringi Pirates of Chatgaon, 1665 A.D.' in Journal of Asiatic Society of Bengal, vol. iii no 6 (June, 1907).

Socarras, Cayetano J. 1966. 'The Portuguese in Lower Burma: Filipe de Brito de Nicote', in Luso-Brazilian Review. vol.iii, no. 2, (December, 1966).

Trindade, Paulo da. 1912. Conquista Espiritual do Oriente. parte 3, Lisboa: Centro de Estudos Históricos Ultramarinos. 